Check for updates

The BMJ

Cite this as: BMJ2020;370:m2997 http://dx.doi.org/10.1136/bmj.m2997 Published: 27 July 2020

\section{Covid-19: Deaths in Yemen are five times global average as healthcare collapses}

Mun-Keat Looi

Yemen's already collapsing healthcare system is buckling as the coronavirus pandemic hits an infrastructure already devastated by five years of war.

A report from the non-governmental organisation MedGlobal and the Center for Global Health at the University of Illinois, USA, ${ }^{1}$ said that 97 healthcare workers had died from covid-19 in Yemen, citing data collected by medical students and local doctors.

Around $18 \%$ of the country's 333 districts already have no doctors, and many of those who remain have been unpaid for nearly two years. MedGlobal said that there were now 10 healthcare workers for every 10000 people, less than half the World Health Organization benchmark.

Yemen recorded its first covid-19 case on 10 April. Official figures put the number of confirmed cases at over 1600 , with nearly 500 deaths ${ }^{2}-$ a mortality rate of $27 \%$, which is one of the highest in the world and five times the global average. This is likely to be an underestimate owing to a severe lack of testing facilities-4865 tests at a rate of 162 tests in a million people-as well as questionable consistency and reliability of figures from the government and rebel forces.

The ongoing conflict means that many cases are probably untraceable. Researchers at the London School of Hygiene and Tropical Medicine, UK, forecast that as many as 11 million could be infected, leading to 62 ooo-85 ooo deaths. ${ }^{3}$

\section{Ongoing problems}

The humanitarian organisation Médecins Sans Frontières has warned ${ }^{4}$ that many of Yemen's healthcare workers have quit their jobs because of fear of infection, while misinformation and the fear of stigmatisation are keeping patients from seeking medical treatment. The country continues to struggle with ongoing outbreaks of cholera and Chikungunya virus.

War had already taken a toll on medical facilities. Only half of Yemen's 5056 facilities are now operational, the rest having suffered a lack of equipment and supplies such as ventilators and oxygen. The MedGlobal report describes a gap in training for personnel, particularly in infection control and isolation units.

Malnutrition is also on the rise, and on 22 July the United Nations warned that food security would affect three million people over the next six months-around $40 \%$ of Yemen's population.

Separately, WHO warned on 22 July that over 10 ooo health workers in Africa had been infected with covid-19. ${ }^{5}$ Preliminary data showed that health workers made up over $5 \%$ of cases in 14 countries in sub-Saharan Africa alone, and in four of these they made up over $10 \%$ of all infections. Of nearly 30 ooo health facilities surveyed, only 2213 had isolation wards and just a third were able to triage patients.

Matshidiso Moeti, WHO regional director for Africa, said, "The growth we are seeing in covid-19 cases in Africa is placing an ever greater strain on health services across the continent. This has very real consequences for the individuals who work in them, and there is no more sobering example of this than the rising number of health worker infections."

WHO has urged governments to ramp up testing capacity and to remain vigilant in the face of a slower rise in cases than in Europe and the Americas. Five countries make up $71 \%$ of covid-19 cases on the continent, South Africa accounting for $43 \%$ alone. ${ }^{6}$

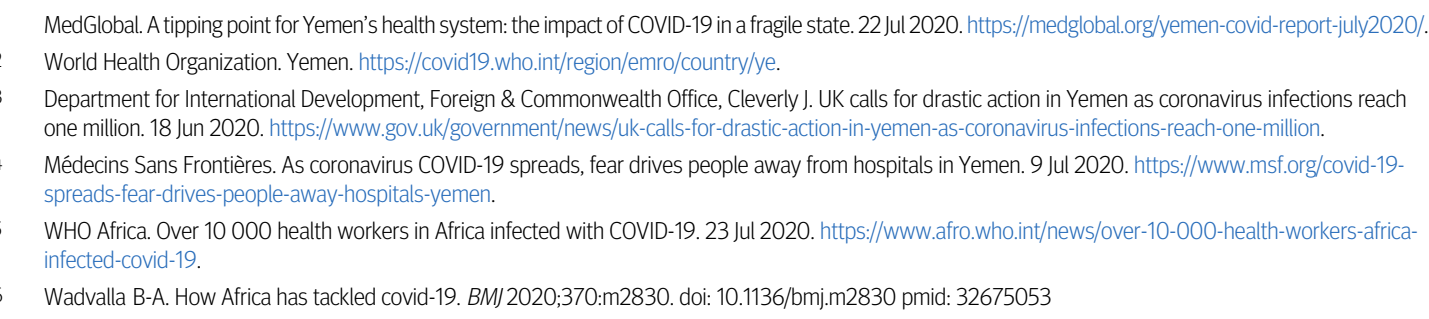

This article is made freely available for use in accordance with BMJ's website terms and conditions for the duration of the covid-19 pandemic or until otherwise determined by BMJ. You may use, download and print the article for any lawful, non-commercial purpose (including text and data mining) provided that all copyright notices and trade marks are retained. 